Rochester Institute of Technology

RIT Scholar Works

3-7-2018

\title{
Institutional Determinants of Environmental Corporate Social Responsibility: Are Multinational Entities Taking Advantage of Weak Environmental Enforcement in Lower-Income Nations?
}

\author{
Stephen R. Luxmore \\ Rochester Institute of Technology \\ Clyde Eiríkur Hull \\ Saunders College of Business, Rochester Institute of Technology \\ Zhi Tang \\ Rochester Institute of Technology
}

Follow this and additional works at: https://scholarworks.rit.edu/article

\section{Recommended Citation}

Luxmore, Stephen R.; Hull, Clyde Eiríkur; and Tang, Zhi, "Institutional Determinants of Environmental Corporate Social Responsibility: Are Multinational Entities Taking Advantage of Weak Environmental Enforcement in Lower-Income Nations?" (2018). Business and Society Review, 123 (1), 151-179. Accessed from https://scholarworks.rit.edu/article/1871

This Article is brought to you for free and open access by the Faculty \& Staff Scholarship at RIT Scholar Works. It has been accepted for inclusion in Articles by an authorized administrator of RIT Scholar Works. For more information, please contact ritscholarworks@rit.edu. 


\title{
Institutional Determinants of Environmental Corporate Social Responsibility: Are Multinational Entities Taking Advantage of Weak Environmental Enforcement in Lower-Income Nations?
}

\author{
Stephen R. Luxmore* \\ Clyde Eiríkur Hull* \\ Zhi Tang* \\ *Saunders College of Business, Rochester Institution of Technology \\ Rochester, New York, United States of America
}

NOTE: This is a pre-proof version of the article, as it was accepted for publication in Business and Society Review. Please refer to the journal website at: http://onlinelibrary.wiley.com/journal/10.1111/(ISSN)1467-8594 for the official version.

\section{Citation information:}

Luxmore, S.R., Hull, C.E., \& Tang, Z. (In press). Business and Society Review.

\begin{abstract}
Multinational enterprises (MNEs) are often accused of taking advantage of lax environmental regulations in developing countries. However, no quantitative analysis of the impact of doing business in nations of different income levels on environmental corporate social responsibility (ECSR) has been done prior to this study. Incorporating institutional factors in our approach, we argue that endoisomorphic and exoisomorphic pressures relating to ECSR impact MNEs differently according to the MNEs' level of activity in low-, lower-middle-, uppermiddle-, and high-income nations. We predict and, using data from 113 companies, find that selling in poorer nations is positively associated with increased levels of ECSR. Our research suggests that MNEs may not be participating in a "race to the bottom" but may instead be responding to global institutional pressure by exceeding local norms for environmental stewardship. Alternative interpretations of our findings are discussed.
\end{abstract}




\section{INTRODUCTION}

Do multinational entities (MNEs) pollute more in countries where they think they can get away with it? How can we understand what makes one MNE pursue environmental corporate social responsibility (ECSR) and another one not? Aguinis and Glavas (2012) suggest that stakeholders' expectations of economic, social, and environmental performance define corporate social responsibility (CSR) and thus influence organizations' CSR policies and actions. Sandhu (2010) proposes that MNEs are increasingly pressured to be environmentally responsible.

Pressures from internal and external stakeholders may explain why MNEs behave as they do. Endoisomorphic pressure, the pressure to conform to standards internal to the MNE, and exoisomorphic pressure, the pressure to conform to the standards of the external environment, may push an organization in different directions (Souitaris et al. 2012). How these pressures interact to influence the ECSR of MNEs has not yet been studied. Our study examines ECSR in an international context, drawing on institutional theory to explore the endoisomorphic and exoisomorphic pressures they face and observe how these pressures interact to shape how MNEs approach ECSR.

Institutional differences are important to international business research, and thus to studying ECSR in an international context (Kolk and van Tulder 2010). Institutional differences influence the scope of strategic options and decision-making ( $\mathrm{Lu}$ et al. 2009; Meyer et al. 2009; Peng 2003; Rothenberg 2007; Tan 2009; Tang and Hull 2012). Peng (2003) argues powerfully that institutional pressures shape strategy, and that strategies change in response to different institutional pressures. Lu, et al. (2009) found that institutional contexts moderate the effects of corporate governance on export behavior. Meyer, et al. (2009) found that MNEs choose different entry modes in different institutional contexts. Rothenberg (2007) studied the differences between environmental managers and environmental performance in two plants 
facing different institutional pressure, and found that institutional differences provoke significant differences in ECSR. Tang and Hull (2012) found that Chinese institutional pressures caused entrepreneurial-oriented companies to behave differently than similar companies in Western markets, while Tan (2009) examined socially irresponsible behavior in MNEs in China using an institutional perspective, finding support for the premise that Chinese institutional pressures encourage irresponsible behavior. Formal regulatory institutions set the rules concerning environmental standards; however, informal institutional factors such as norms and ethics shape what is acceptable with respect to adhering to formal regulations. And the array of institutional settings MNEs face complicates how strategic ECSR works (McWilliams and Siegel 2011). In our study the classification of economies using the World Bank income classification captures whether formal institutions or informal institutions dominate the rule-setting system.

Consider the institutional context in developing nations, which are vulnerable to economic exploitation, including environmental degradation (Arora and Dharwadkar 2011; Hart 1995). MNEs may see this vulnerability as an opportunity to reduce costs, or as an opportunity to create a sustainable competitive advantage through environmental stewardship (Hart 1995; Mross and Rothenberg 2007; Porter and Kramer 2011). But which opportunity MNEs pursue will vary according to the full set of endo- and exoisomorphic pressures they face. To try to answer the following question, our study examines ECSR-related pressures on MNEs:

When do the effects of endoisomorphic and exoisomorphic pressures lead MNEs to exploit weak environmental regulations in host countries, and when do they lead MNEs to do more than the regulations require?

Our approach to this question is quantitative rather than qualitative. Rather than studying a single company in depth, we study over 100 companies, and conduct statistical analysis on the 
resulting data. This quantitative approach supplements qualitative approaches, allowing us to build on studies such as Souitaris, et al. (2012), whose rich and in-depth examination of six corporate venture capital programs helped lay the foundation for the present study. While the present study lacks the detail of a qualitative approach, our large sample size offers the advantage of more generalizable findings. Our study builds on theoretical and qualitative work to statistically examine the effects of endoisomorphic and exoisomorphic pressures on MNE behavior.

We next briefly review the CSR and ECSR literature, and then develop our hypotheses. Our sample, data collection, measures, and analysis follow in the methods section. We then present the results and discuss our findings, potential directions for future research, and our study's implications.

\section{ENVIRONMENTAL CORPORATE SOCIAL RESPONSIBILITY INTERNATIONALLY}

ECSR is increasingly important to managers (Aguilera-Caracuel, Aragon-Correa et al. 2012; Aguilera-Caracuel, Hurtado-Torres et al. 2012; Holtbrugge and Dogl 2012). The relationship between social benefit and corporate performance does not have to be a zero-sum game (Porter and Kramer 2006), but businesses have not fully recognized the benefits of ECSR (Mross and Rothenberg 2007; Porter and Kramer 2011). Not all environmental practices lead to competitive advantage (Basu and Palazzo 2008). Hart (1995) argues the firms may engage in ECSR along three dimensions: controlling and preventing pollution; minimizing environmental product life cycle cost; and achieving sustainable development to harmonize economic activity and the environment. ECSR often involves exceeding legal requirements, particularly where requirements are low (Chiu and Sharfman 2011). 
As legal requirements may vary from country to country, managing ECSR is more complex for MNEs than for domestic companies. For example, two similar plants in different countries, with the same parent MNE, approached environmental performance differently because of local differences in institutional pressure (Rothenberg 2007). A case analysis of a dozen mining firms found that home-nation norms may influence subsidiary ECSR, but while there is increasing environmental and other CSR activity in emerging markets, MNEs tend to stoop to host nation standards when those standards are lower (Gifford et al. 2010). Other case studies have yielded similar results (Eweje 2009; Muthuri and Gilbert 2011), a common finding being that subsidiary managers believe they should meet only the lower standards of the nations in which they operate.

Nations may be engaging in a "race to the bottom," a rush to reduce environmental and other regulations to attract and retain predatory MNEs (Madsen 2009; Williamson et al. 2006). If so, MNEs may face exoisomorphic pressure to take part in this unseemly race. In Lebanese cases, weak formal regulatory institutions discouraged CSR (Jamali and Mirshak 2007, 2010). Halter and de Arruda (2009) show that MNEs exploit developing nations with weak formal institutional constructs, as a lack of transparency promotes corruption. A recent longitudinal study (Tang and Smith 2012) suggests that governments in developing economies help companies they favor elude pressure to be environmentally responsible. Decision-makers in host countries may be pressured into lowering their standards if local norms are lower than in their home nation (Bailey and Spicer 2007; Kliukinskaitè-Vigil 2011). Or MNEs may enter markets with low environmental standards specifically to exploit those standards, just as criminals may be drawn to areas where the law is weak in order to better pursue their criminal activities (Arora and Dharwadkar 2011; Ghemawat 2007). 
On the other hand, MNEs may choose to exceed local environmental standards (Christmann and Taylor 2001; 2006). Local managers may push for higher standards than are required locally (Reimann et al. 2012), and firms active in poorer nations have been shown to achieve higher environmental performance (Baughn et al. 2007; Chapple and Moon 2005; Kennelly and Lewis 2002; Shah and Rivera 2007). In particular, Baughn et al. (2007) found that CSR activity is subject to home nation pressures: MNEs behave better abroad if based in nations with strong rather than weak formal institutional pressure. Mross and Rothenberg (2007) found that internal pressure from top management drove environmental performance, suggesting that an MNE's internal environmental standards may outweigh external institutional pressures.

MNEs might not simply adopt home or host national standards. China-based managers have been found, contrary to expectations, to attribute greater importance to stakeholders than do U.S.-based managers (Shafer et al. 2007). Lo et al. (2008) found no significant differences in environmental policy in firm-reported levels of CSR for Chinese and U.S. firms. In Rothenberg's (2007) two-plant study, managers in the plant facing weaker local environmental regulations were motivated by pressure from inside the MNE, while in the plant facing stricter local regulations, managers were primarily concerned with keeping external forces at bay. MNEs tend to invest in nations with environmental standards similar to their home markets, suggesting they try to avoid nations that require changes to their environmental policies (Madsen 2009). Thus, how MNEs adjust their environmental performance in relation to external institutional factors is not yet established. 


\section{INSTITUTIONAL THEORY AND ENVIRONMENTAL CSR ACROSS NATIONAL BORDERS}

Firms take actions, including environmental ones, to improve the bottom line and create competitive advantage (Kim and Statman 2012; McWilliams and Siegel 2011; Porter and Kramer 2006, 2011). Some evidence indicates high ECSR leads to improved financial performance (Clarkson et al. 2011; Pils and Rothenberg 2003; Russo and Fouts 1997; Waddock and Graves 1997). Yet the finding of a non-linear relationship between environmental and financial performance suggests that managers may adjust ECSR in response to isomorphic pressures (Kim and Statman 2012). If they do adjust to this pressure, variation in institutional factors may cause variation in how they approach ECSR. For firms operating across multiple borders, local institutional contexts affect competitive advantages such as those stemming from high ECSR (McWilliams and Siegel 2011; Moss 2005), so an MNE's strategic environmentalism could differ from country to country. Both formal and informal institutions are central to the strategic opportunities and behaviors of firms, including environmental performance (Hitt et al. 2004; Meyer et al. 2009; Peng 2003; Rothenberg 2007). Thus the institutional contexts that shape an MNE's environmental strategy are likely to vary significantly according to differences in institutional pressures (Tang and Hull 2012).

MNEs may face external pressures from home- and host-country institutional factors and from global institutional factors. High-income nations generally exert the strongest national institutional pressure to enact the highest level of environmental performance. The pressure is lower in middle-income nations (and lessens from upper- to lower-middle income), and lowest in low-income nations (Chapple and Moon 2005; Eweje 2009; Gifford et al. 2010; Halter and de Arruda 2009; Husted and Allen 2006; Li et al. 2010; Muthuri and Gilbert 2011). This correlation 
is one of the few things about which research in this area is in general agreement. Our study thus focuses on the environmental performance of MNEs across nations of different wealth levels, and is the first study we know of to use quantitative data to empirically evaluate the impact of MNE activity in low-, lower-middle-, upper-middle-, and high-income nations on environmental corporate social responsibility.

While MNEs face multiple national institutional environments, each exerting isomorphic pressures on subsidiaries to conform (Bailey and Spicer 2007; Kliukinskaitè-Vigil 2011), national exoisomorphic pressures may not wholly determine strategic decisions (Souitaris, et al. 2012). MNEs may face global exoisomorphic pressures, such as NGOs seeking global improvements to ECSR practice, industry association influences, or global standards. When global organizations exert the greatest isomorphic pressure, MNEs may be moved to increase ECSR in tandem with international expansion to maintain or improve international legitimacy (Aguilera-Caracuel, Hurtado-Torres et al. 2012; Bansal 2005). In this situation global exoisomorphic pressures are dominant. When national pressures dominate, subsidiaries acquiesce to local institutional pressures, so the same MNEs have different levels of ECSR in different countries.

Or subsidiaries may follow parent policies when endoisomorphism - internal environmental pressure - drives MNE decision-making (Souitaris et al. 2012). Friedman (1970) suggests that the business of business is to earn profits. This perspective, epitomized by the questionable adage - "If you aren't cheating you aren't trying hard enough." - seems to obligate businesses to play dirty to maximize profits. By this view, MNEs cannot be trusted to behave ethically (Arora and Dharwadkar 2011; de Jonge 2011). Responding to endoisomorphic 
pressure, they exploit the lowest standards, taking advantage of countries where environmental regulations are weak (Ghemawat 2007).

But managers often try to live up to their home-nation standards (Kliukinskaite-Vigil 2011; McDonald and Kan 1997). If they realize that ECSR is profitable, MNEs can choose a strategy of environmental responsibility for financial reasons (Campbell 2007; Kim and Statman 2012; Mross and Rothenberg 2007; Porter and Kramer 2006, 2011; Price 2008; van Beurden and Gössling 2008). Thus if home-nation environmental standards are high and they believe environmental responsibility increases profits, managers in countries with low environmental standards will try to exceed those standards (Campbell 2007; McWilliams and Siegel 2011). The endoisomorphic pressure to maximize profits may thus manifest itself as a drive either to exploit or to exceed lower standards.

MNEs tend to standardize to improve performance (Levitt 1983) and managers may prefer their home-country standards (Kliukinskaitè-Vigil 2011). Standardization may improve ECSR (Aguilera-Caracuel, Hurtado-Torres et al. 2012; Christmann and Taylor 2006, 2003). MNEs in which endoisomorphic pressure dominates and managers believe standardized ECSR optimizes financial performance will standardize their ECSR in all markets. The exoisomorphic pressures resulting from internationalization are relatively unimportant to them and do not affect their ECSR.

MNEs may favor exploitation when possible (Arora and Dharwadkar 2011; Madsen 2009; Shafer et al. 2007; Tan 2009), leading to a standardization strategy in which the parent MNE directs its subsidiaries to exploit local institutional weaknesses. In such cases the endoisomorphic pressures to exploit lax institutional pressures align with national exoisomorphic pressures for lower standards, and the MNE may push for even lower standards. 
Because the institutional differences among these nations are so large, it seems reasonable to expect that no one isomorphic pressure will dominate in each income category. In some situations, endoisomorphic pressures may dominate, in others, exoisomorphic. No one endo- or exoisomorphic pressure dominates ECSR choice in every income-level market. The effect of sales in each of the four income-level categories on environmental performance will vary depending upon which isomorphic pressure is the strongest in that category.

Hypothesis 1. We will observe different relationships between sales and environmental performance of MNEs in nations of different income level.

Sales in each income-level category may positively, negatively, or insignificantly affect an MNE's ECSR. If national exoisomorphic pressures to localize environmental standards dominate in lower-income nations, those pressures will have a negative effect on ECSR. Strong endoisomorphic pressures to exploit lax environmental standards in lower-income nations would have a similar effect. But we do not expect these pressures to be dominant. Home-nation institutional pressures for ECSR are usually high, and poor ECSR anywhere could hurt the firm's reputation at home and put the expected financial benefits of ECSR at risk (McWilliams and Siegel 2011). If global exoisomorphic pressures dominate, we will observe a positive relationship between sales to lower-income-level categories and MNEs' environmental performance.

A strategy of applying home-nation standards globally, driven by endoisomorphic pressures to standardize, may not capture all the benefits of ECSR. If the MNE optimizes its ECSR only on a home-country basis, the firm forgoes the potential global benefits of ECSR. 
Global exoisomorphic pressures may push MNEs to use environmental strategies that exceed home-nation standards, improving firm performance (Campbell 2007; Porter and Kramer 2006). McWilliams and Siegel (2011) argue that high environmental performance leads to competitive advantage due to (1) reputational effects, (2) personnel cost advantages, and (3) capital cost reductions. The reputational effects enhance revenue and lower cost (McWilliams and Siegel 2011). For MNEs, the lowered costs may include foreign market entry cost. Many MNEs could bring capital, managerial know-how, technical know-how, and similar competencies to markets lacking these factors. But all else equal, MNEs known to be careful about polluting may be preferred over rivals. We predict that for markets with lower environmental institutional standards, MNEs will prefer a positive environmental performance strategy to one of exploitation or standardization.

Hypothesis 2. Sales to low-income nations are positively associated with MNE ECSR. Hypothesis 3. Sales to lower-middle-income nations are positively associated with MNE ECSR.

Dominant exoisomorphic pressure will lead firms to adopt similar ECSR policies, but dominant endoisomorphic pressure may not. Endoisomorphic pressure will be more dependent on factors other than the nations in which MNEs do business. Upper-middle-income nations exert greater institutional pressure for ECSR than do lower-middle- and lower-income nations. We do not expect endoisomorphic pressures to exploit local environmental standards to dominate in upper-income nations because: (1) the potential benefits are lower in upper-middle-income nations, and (2) the negative reputational effects are too great. 
But in upper-middle-income nations the exoisomorphic pressure to conform to global standards will not be as high as for low- and lower-middle-income nations. Upper-middleincome nations have higher ECSR expectations than poorer nations, and the marginal benefit of increasing ECSR will be lower. Low-income nations have high ECSR potential; high-income nations do not (Lauder 2010). Endoisomorphic pressures concerning ECSR in this setting, while perhaps strong, may vary considerably from firm to firm. For the same reasons that regulations concerning ECSR are stricter in upper-middle-income nations than in lower-income nations, the ability to realize differentiation advantages rather than cost advantages will be higher, and MNEs may be motivated to differentiate based on something other than ECSR in upper-middle-income nations. Innovation and marketing are such alternatives, known to work (Hull and Rothenberg 2008; McWilliams and Siegel 2000) so long as the repercussions of exploitative actions can be controlled (Miles et al. 2002, 2004; Tang and Smith 2012). The effort required to exceed local standards in upper-middle-income nations is considerably greater than it is in poorer nations with lower standards, so if endoisomorphic pressure dominates, it will be the pressure to standardize. Standardizing lets MNEs satisfy national standards and conserve their resources to invest in other differentiating factors that yield higher returns in upper-middle-income nations. This leads to our next hypothesis:

Hypothesis 4. We will not observe a significant relationship between sales to upper-middleincome nations and MNE ECSR.

In high-income nations, with the strongest national exoisomorphic institutional pressure to achieve high levels of ECSR, MNEs will generally pursue ECSR. Wealthier nations can afford 
to be more concerned about the long-term effects of polluting and other environmentally unsound practices. In these nations, the reputational benefits, personnel cost advantages, and capital cost reductions stemming from high environmental performance (McWilliams and Siegel 2011) are matched with strong penalties for failing to meet local standards (Miles et al. 2002, 2004). MNEs are thus more vulnerable to institutional pressures in these nations than they are in others. MNEs prefer a consistent policy across all nations in which they operate, and the endoisomorphic pressure to standardize is greatest when they operate in nations with similar exoisomorphic pressure for high levels of ECSR (Madsen 2009). It may be that institutional pressures in wealthy nations are such that it is most profitable to pursue high environmental performance in all of them (Porter and Kramer 2011). Endoisomorphic pressure to exploit lax environmental situations will be minimal. If an MNE is disposed toward a strategy of exploitation, there are better opportunities to pursue such a strategy in lower-income nations. The exoisomorphic pressure to meet global standards will not be the dominant pressure because the global standards originate in the wealthiest nations, and national standards will resemble the global standard. Instead, endoisomorphic pressures to standardize will dominate. Thus, our last hypothesis:

Hypothesis 5. We will not observe a significant relationship between sales to high-income nations and MNE ECSR. 


\section{METHODOLOGY}

\section{Sample and Data Collection}

We identified companies for our study from the widely used Environmental, Social, and Governance factors (ESG) database maintained by Morgan Stanley Capital International (MSCI). The MSCI ESG Indices are the current form of the indices developed over the past 20 years by Kinder, Lydenberg, and Domini (KLD); these indices were acquired by MSCI in 2010. We matched this dataset with the companies' financial data (including activity in different markets) from the Compustat database. Because Compustat has limited data on international activity, we identified only 113 firms with complete data.

\section{Measures}

\section{Dependent variable}

We adopt the 2009 environmental performance measure from the ESG dataset. In this dataset, the ESG's environmental performance scale includes two categories with seven dummy items for positive performance (or strengths) and seven dummy items for negative performance (or concerns). As is common with studies using the KLD/ESG data set (e.g., Hull and Rothenberg 2008), we calculated the 2009 environmental performance measure by deducting the sum of the seven concern items from the sum of the seven strength items, creating a continuous variable as our dependent variable.

\section{Independent variables}

In a study of the effects of FDI and portfolio investment flows on economic growth, de Vita and Kyaw (2009) argue that the World Bank country classification system, which is based on gross national income per capita, captures institutional differences. Using a dynamic panel model and a large data set spanning 126 countries over an 18-year period, they empirically 
confirm the existence of differing effects by World Bank country classifications (de Vita and Kyaw 2009). We anticipate that their study will set a standard, given their extensive demonstration of how the World Bank classifications capture institutional differences, and the ease with which the typology they demonstrate can be used. Using their system, we classify the countries in which any of the 113 companies in our sample has sales according to the four World Bank categories: high-income market, upper-middle-income market, lower-middle-income market, and low-income market. The average of a company's percentage of sales in each market out of total sales in both 2007 and 2008 is used to measure each type of market's importance to that company. We use the two-year average to curb abnormal fluctuation in the annual sales value.

\section{Control variables}

We controlled for variables that have been found to affect the likelihood of a firm's pursuing environmental performance. The first, organizational slack, is "a cushion of actual or potential resources which allow an organization to adapt successfully to internal pressures for adjustment or to external pressures for change in policy, as well as to initiate changes in strategy with respect to the external environment" (Bourgeois 1981, p. 30). Slack has a positive impact on social performance (Bowen 2002; Sharma, 2000). The more slack resources a firm has, the more it can spare for pollution prevention, recycling, and other elements of environmental performance. We included the average ratio of long-term debts to total assets for 2007 and 2008 to control for slack (Chatterjee 1990; Reuer and Ragozzino 2005; Singh 1986). This ratio is an inverse measure of organizational slack. The smaller the ratio, the more slack the firm has, since it has less need to go outside for funding. 
We also controlled for firm size, as larger firms may have a stronger motive to engage in good environmental practices. The larger they are, the more visible they are, so they stand to benefit more from a good reputation and to suffer more from a bad one. Even the most cynical large firms may not want to be a target for government regulations and NGO campaigns (Luxmore and Hull 2011; Miles et al. 2002, 2004). Larger firms may also be better able to handle complicated environmental strategies, as they are more familiar with diversified operations. To control for the effects of firm size we included the logarithm of the number of employees the company had in 2009 in our model. As a robustness check, we ran our equations again controlling for the logarithm of total assets instead of number of employees, and obtained essentially the same results, with the same level of support for all hypotheses. We retain the employee-based measure because another one of our variables, organizational slack, is based in part on total assets. Using the number of employees thus reduces multicollinearity issues.

Because the industry in which a firm competes may impact the relevance of environmental practices, we included this in the model as well. Industry is a dummy variable, with 1 indicating manufacturing industries and 0 indicating service industries.

Past environmental performance is a good predictor of future environmental activity, so we included the firm's 2007 and 2008 average ESG environmental score, the deduction of the sum of the concern items from the sum of the strength items, in our model.

\section{ANALYSIS AND RESULTS}

We used multivariate linear regression (OLS) to analyze the hypotheses. Table 1 shows the means, standard deviations, and correlations of the model variables. It indicates that past environmental performance has a significant relationship with the 2009 environmental performance $(r=.99, p<.001)$. This confirms that it is necessary to control for past 
environmental performance when looking at the predictive effects of other variables on environmental performance. We adopted a common practice in the economics and finance literature for controlling the instrumental effect of a dependent variable (e.g., Ahuja and Katila 2001; Baum et al. 2007). Based on the logics of path dependency, a firm's financial or social performance is heavily affected by its prior performance (Alarcon and Sanchez 2013). For example, a firm's profitability in one year is often heavily influenced by its profitability the previous year and the resources and slacks generated by last year's profitability. Thus, controlling the instrumental variable, i.e., previous ECSR, allows us to more accurately predict the changes in our dependent variable, which will be reflected by a high R-square. Environmental performance has a significantly positive relationship $(r=.19, p<.05)$ with the lower-middle-income market only. The lack of significant correlation of 2009 environmental performance with other market types may warrant further analysis.

Table 2 summarizes the hypothesis test results. Model 1 includes all covariates and shows that past environmental performance has a very strong relationship with 2009 environmental performance $(\beta=.99, p<.001)$. Model 2 , in which we added the four market variables, indicates that the signs across all four market types are not the same: three are positive and statistically significant, while the fourth is negative, but not significant. Thus Hypothesis 1 is supported. No one isomorphic pressure dominates at all four income levels. The results indicate that sales in low-income nations have a positive relationship with $\operatorname{ECSR}(\beta=.04, \mathrm{p}<.05)$, as do sales in low-middle-income nations $(\beta=.04, \mathrm{p}<.05)$. Hypotheses 2 and 3 are thus supported. This suggests that exoisomorphic pressures to conform to global standards are dominant in both low-income and low-middle-income nations. Consistent with our Hypothesis 4, sales in uppermiddle-income nations do not seem to affect ECSR ( $p>$.10). Sales in high-income nations, 
however, seem to be strongly and positively related to $\operatorname{ECSR}(\beta=.09, \mathrm{p}<.001)$. This finding does not support our Hypothesis 5.

Insert Tables 1 and 2 about here

Table 1 reports a high correlation between the upper-middle income and high-income markets $(-0.60)$. The correction coefficient of 0.99 between past environmental performance and 2009 environment performance is unusually high. Other correlation coefficients for different income categories are also high suggesting a problem of multicollinearity. However, in all model testing, no Variance Inflation Factor (VIF) in our moderation analysis was higher than 2.34, far below the threshold value of 10 (Perrini et al. Tencati, 2007). Thus, we believe that multicollinearity is not responsible for our findings.

\section{DISCUSSION}

Four of our five hypotheses are supported. Though not all specifics were as we predicted, no one isomorphic pressure dominates at all four income levels. Doing business in low- and low-middleincome nations is positively related with ECSR, but we found no significant relationship between doing business in upper-middle-income nations and ECSR. However, we also found a strong positive relationship between doing business in wealthy nations and environmental performance. Thus it appears that MNEs do see ECSR as a means of increasing profits in high-income nations.

Our findings are consistent with the premise that MNEs are now proactive about ESCR, driven primarily by exoisomorphic pressures to meet global ECSR standards. MNEs may be more aware of the profit potential associated with ECSR (McWilliams and Siegel 2011; Porter and Kramer 2011). It could be that pressure from NGOs, home governments, and other 
international efforts are altering the competitive landscape (Luxmore and Hull 2011; Miles et al. 2002, 2004). Perhaps stakeholders trust only MNEs with high environmental standards to enter countries with weak environmental regulations (Dam et al. 2007). Firms with more sales in lowincome or lower-middle-income nations had higher scores on environmental performance than did firms with fewer sales in these nations. Given that the companies in this sample are publicly held and thus particularly vulnerable to endoisomorphic pressure to maximize profits, a reasonable conclusion is that these MNEs consider a proactive approach of exceeding environmental standards to be the most profitable one (Mross and Rothenberg 2007; Porter and Kramer 2006, 2011).

Contrary to our arguments, sales in high-income nations are linked to ECSR. It appears that exoisomorphic pressures in high-income nations are strong enough that practitioners in these nations strive to improve their environmental performance. If reputation is a significant contributor to the financial rewards of environmental performance (McWilliams and Siegel 2011), then environmental performance may be valued most in settings where reputation matters the most. In the nations with highest standards and greatest focus on environmental impact, institutional pressure could yield the greatest rewards for responsible environmental behavior and the greatest penalties for poor environmental performance. Meeting these standards might be challenging, but also rewarding. Innovation and CSR in general are correlated (McWilliams and Siegel 2001), but innovations are more likely to occur when there is a market for them. Innovations related to environmental performance could thus be expected most often in highincome nations. Assuming reasonable levels of technical parity and absorptive capacity (Cohen and Levinthal 1990; Delmas et al. 2011; Hull and Covin 2010; Tang et al. 2012), firms active in 
these settings may find frequent opportunities to observe and absorb new ECSR best practices (Aguilera-Caracuel, Hurtado-Torres et al. 2012).

Our findings are based on data from 113 publicly held companies. While this sample is larger than those in the case studies on which this study is built, it is still small enough that the results may not be broadly generalizable. Reexamining our research questions with another sample, perhaps drawing on a different source than the ESG dataset, would address this issue.

The environmental movement has been successful in recent years in part because pollution affects the entire planet - what happens to the environment elsewhere may feel local to people in high-income countries. Self-interested citizens in such countries might be inclined to cause trouble for polluting companies, but to ignore other dimensions of CSR, such as human rights activities. It would be instructive to see if these other dimensions are similarly impacted by the nations in which an MNE competes. Also, since some environmental initiatives pay better than others (Campbell 2007), could first-mover status with a very profitable ECSR initiative let companies "double-dip" or "many-dip" by being first in multiple nations with expectations much lower than in their home country?

The globalization of environmental-related institutional pressures from wealthy nations appears to have reached low-income and lower-middle-income nations, but upper-middleincome nations appear to have resisted the imposition of the wealthier nations' standards. Why this should be so is another interesting research question. If global exoisomorphic pressures for high ECSR were universally dominant, we would expect to see MNEs treating the environment the same regardless of where they were. There is some evidence for a trend in this direction, both in the observation that MNEs are becoming more aware of the financial benefits of high environmental performance (Mross and Rothenberg 2007; Porter and Kramer 2006, 2011) and in 
the fact that the "race to the bottom" in the poorest nations appears to have turned into a race to the top. Upper-middle-income nations' standards may be higher than those of lower-income nations, but there may be no exoisomorphic pressure to exceed those standards, perhaps because expectations have not been raised or because of corruption (Qerimi and Sergi 2012).

There is a darker alternative explanation to consider. That data indicate firms active in lower-income nations tend to be more environmentally responsible may be a function of poor or missing information. The MSCI ESG dataset has been used extensively to capture CSR and its dimensions since Waddock and Graves (1997) proposed and tested the dataset as an objective, reliable means of evaluating the social performance of publicly held companies. But the dataset is based on available information. While technology has improved the flow of information around the world, a toxic chemical spill or other environmental bad practice in sub-Saharan Africa might get less attention than the same practice in the Netherlands or some other highincome country. Some governments let companies get away with polluting if they have a financial interest in the success of the polluting companies, suggesting that governments and companies may collude to keep evidence of poor environmental performance from coming to light (Tang and Smith 2012).

Not only environmental standards vary across nations, so do the levels of monitoring and compliance, and these variations in governance quality affect MNE behavior (Kolk and van Tulder 2010; Slangen and van Tulder 2009). Some MNEs may have learned to seek out the nations that have the lowest monitoring and compliance expectations. Corruption impedes economic development, implying a correlation between corrupt institutional settings and lowerincome nations (Qerimi and Sergi 2012). Rather than being more responsible, MNEs may be getting away with more in low-income nations, partly because news from those nations rarely 
reaches the rest of the world, and partly, perhaps, because they are so good at encouraging the "race to the bottom" (Arora and Dharwadkar 2011; Williamson et al. 2006) that their misdeeds go not only unpunished but unrecorded (Halter and de Arruda 2009). They could even be outsourcing the pollution, establishing partnerships with local businesses unaffected by global exoisomorphic pressure and shielded by their own governments from negative repercussions of negative ESCR (Tang and Smith 2012).

This darker alternative interpretation explains our findings disturbingly well: MNEs pursue environmental performance in high-income countries, but not in other nations. In uppermiddle-income nations, MNEs meet standards but do not try to exceed them. Their environmental performance in poorer nations is bad, but so well concealed that they seem to be environmental contributors. A related point is that our findings are based on sales in these countries. More exploitive behavior might be seen among MNEs whose business in these poor nations is more focused on extracting natural resources, and thus they buy rather than sell.

Technological barriers to transmitting information across the world may have diminished, but cultural and political barriers persist. The same pressures that might drive a company to seek the more responsible path could also drive it to try harder to find ways to sweep its less responsible behavior out of sight. Environmental performance benefits are more related to avoiding negative attention from outside entities than are the benefits of socially responsible practices concerning the treatment of employees or the creation of better products (Miles, et al. 2002, 2004). This makes environmental performance ideal for measuring corporate behavior in less-regulated lower-income nations, but it also means that our results need to be approached with caution. Do they mean that corporations are contributors to the greater good in these countries, or that harmful, criminal actions are being effectively concealed? We need further 
scrutiny of whether these companies are good, or just good at not getting caught. Environmental activists and business ethicists might even consider it an obligation to shine the light of inquiry more brightly into MNE activities in these nations.

\section{CONCLUSION}

This study contributes to the literature by examining the exoisomorphic and endoisomorphic pressures on MNEs with respect to ECSR, and by empirically confirming the predicted effects using the World Bank approach to market classification developed by de Vita and Kyaw (2009). Using data from the World Bank, Compustat, and ESG, we were able to analyze our hypotheses using complete data from 113 MNEs.

The confirmation of our first hypothesis, that relationships between sales and environmental performance of MNEs differ in nations of different income levels, suggests that in nations of different income levels environmental performance differs in other ways as well. The question of whether MNEs in low-income and middle-income nations are finding it easier to exceed environmental expectations or simply finding it easier to get away with pollution suggests at least one potential difference between polluting in a wealthy nation and a poor one. There may be others.

That doing business in low- and middle-income nations is positively and significantly related to environmental performance - our second and third hypotheses - may seem counterintuitive to some. We hope that this leads to further examination of the question, and of environmental performance among MNEs active in these countries. Doing business in highincome nations positively affects environmental performance, contrary to our expectations (Hypothesis 5). This finding makes the predicted (Hypothesis 4) and empirically supported lack 
of effect of doing business in upper-middle-income nations perplexing. Why the U-shaped relationship?

One possible answer is that endoisomorphism is responsible for environmental performance in low-income and middle-income nations, where exoisomorphic pressure is low, that endoisomorphic and exoisomorphic pressures are balanced in upper-middle-income nations, and that exoisomorphic pressure is higher than endoisomorphic pressure in upper-income nations, as shown in Figure 1 below:

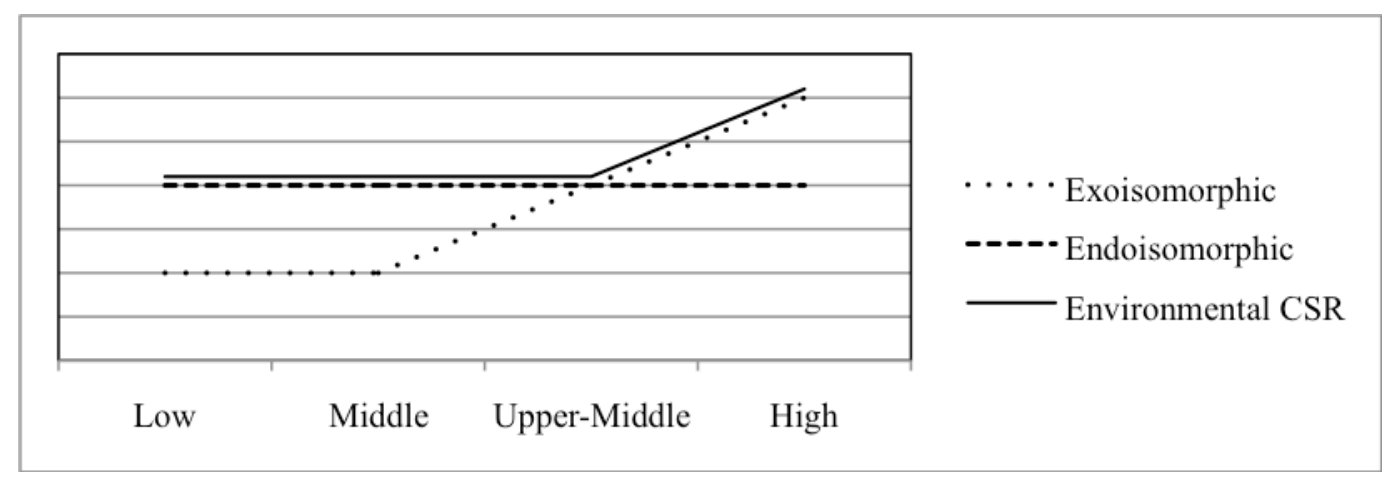

\section{Figure 1 - Exoisomorphic and Edoisomorphic Pressures Across National Types (Endoisomorphic Pressure Contributes to Environmental CSR)}

Consistent with our results, this figure suggests that endoisomorphic pressure to be environmentally responsible is higher than exoisomorphic pressure in low- and middle-income nations, and is the cause of higher environmental CSR than expected. While not explicitly researching the source of CSR activity, Blodgett et al. (2014) suggest that corpoarate performance goals are better attained for MNEs when environmental CSR activity exceeds local requirements in countries or regions with low standards. In upper-middle-income nations, the exoisomorphic pressure is close enough to endoisomorphic pressure that neither has more effect - meaning that MNEs tend to simply follow local regulations here. In high-income nations, 
however, the exoisomorphic pressure is higher than the MNE's internal standards, and the MNE is forced to conform to those standards.

But our alternative interpretation discussed above is that MNEs are not actually being more environmentally socially responsible in low- and middle-income nations. Figures 2 and 3 below illustrate this possibility. If this is correct, endoisomorphic pressure does not exceed exoisomorphic pressure in any country. The pressure to do "good" in less wealthy nations is what drives environmental CSR, as it does in the wealthier nations. But if this is so, why the performance differences we found? The answer, we fear, is perhaps cynical.

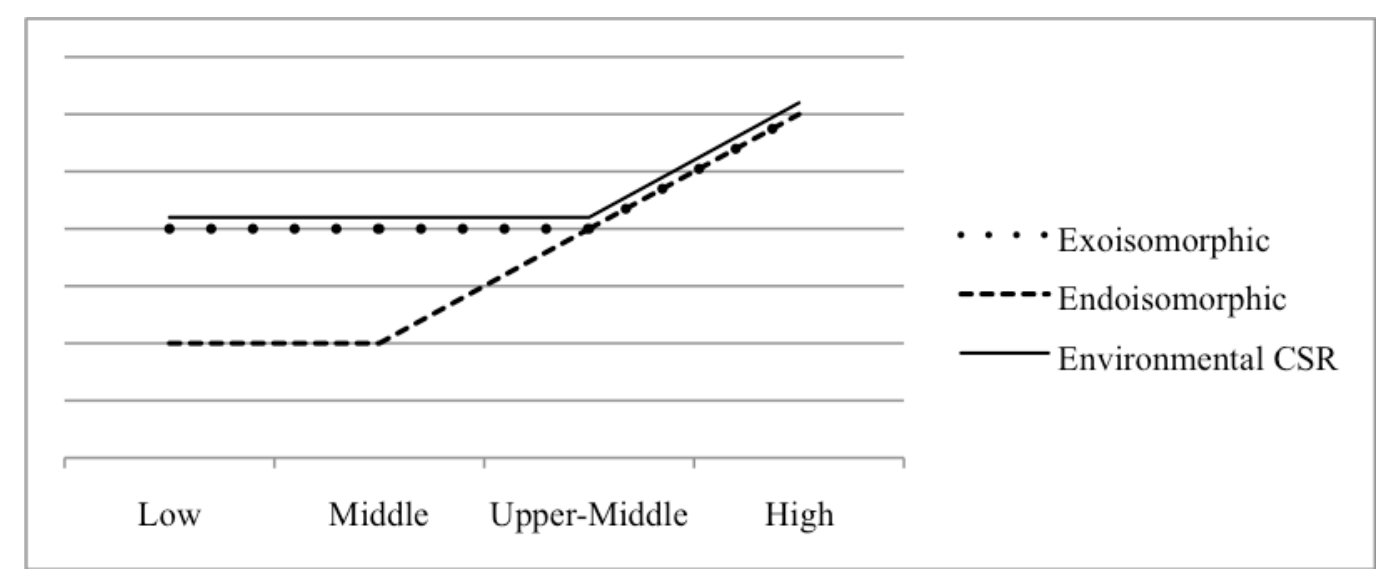

\section{Figure 2 - Exoisomorphic and Edoisomorphic Pressures Across National Types (Endoisomorphic Pressure Matches Environmental CSR)}

Figure 2 illustrates the possibility that endoisomorphic pressure has negligible effects on environmental CSR, perhaps rising to match the levels of external isomorphic pressure in uppermiddle and high-income nations. Figure 3, below, illustrates the possibility that, with the exception of a few idiosyncratic companies, MNEs respond to exoisomorphic pressure, and exoisomorphic pressure alone, in determining their environmental behavior. 


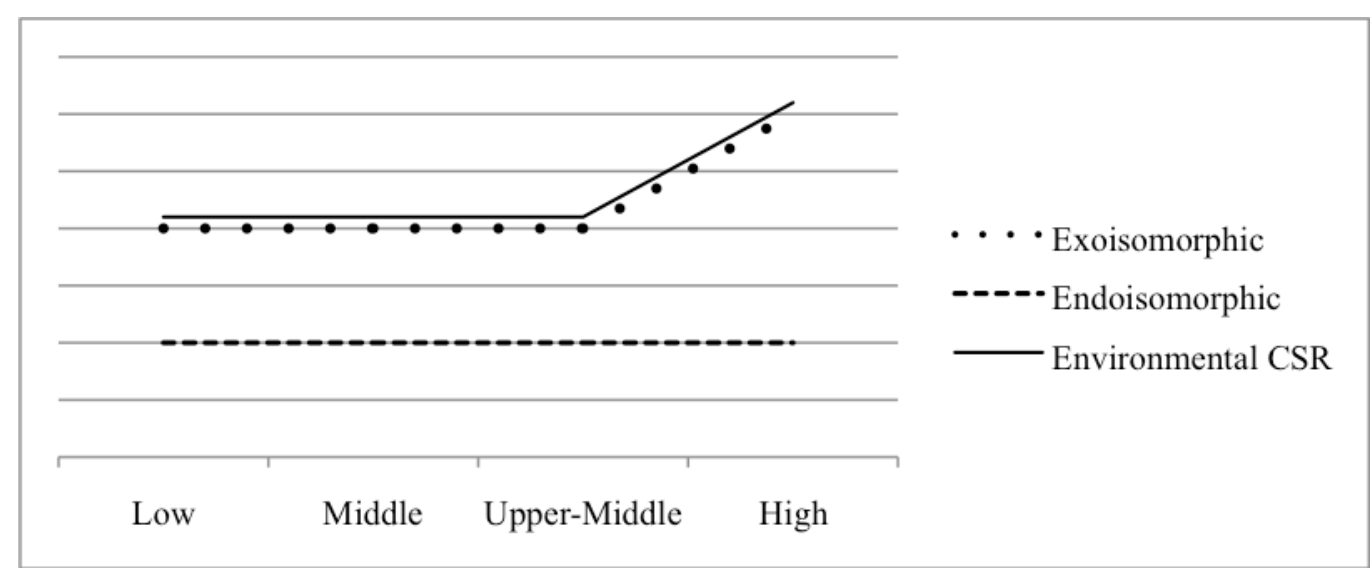

\section{Figure 3 - Exoisomorphic and Edoisomorphic Pressures Across National Types (Endoisomorphic Pressure Is Negligible)}

This returns us to the possibility that MNEs are not actually more responsible in nations with poor environmental standards, or with poor enforcement of their standards. They may simply find it easier to hide or outsource their misdeeds. Our data reflect only observed behavior, not hidden crimes a company may have committed. Companies such as Nike and Apple have occasionally gotten unwanted attention for the behavior of their suppliers in lowincome nations. They were able to shift a portion of the blame by pointing out that the reprehensible behavior was committed by their business partners, not by them. While Apple's and Nike's denials of any knowledge of their partners' actions may be true, it seems plausible that other companies knowingly seek out such partners. If local companies in low- and middleincome countries willingly pollute and otherwise misbehave on behalf of their MNE partners, then the high environmental CSR scores of these MNEs is, while technically correct, a sign not of responsible behavior, but of skill at gaming the system. As there is a powerful school of thought (Friedman 1970) that argues in favor of gaming any system to maximize shareholder return at any cost to other stakeholders, including the environment, this interpretation seems quite likely. 
A theoretical concern emerging from this study is that the long-discussed difficulty in obtaining accurate results may have recurred after having been considered adequately addressed ever since Waddock and Graves (1997) introduced the use of what was then called KLD data. If, since these data were first introduced, companies have been analyzing the "test" and how it is scored, we should expect that the "test" (i.e., the KLD data) may have become less accurate. Archival data from the first few years they were collected, when few companies knew or cared about their KLD ratings, may be the most reliable data from the dataset. An unexpected alternate source of information might also help obtain more accurate results.

Practical implications vary for different stakeholders. For MNEs and their lawyers, the practical implication, regrettably, may be that the most profitable approach to environmental CSR is to outsource pollution to a well-controlled partner in a nation with low exoisomorphic pressures. For policy makers, the implication appears to be that current policy is not sophisticated enough to reward true environmental responsibility, though strong enough to conjure its appearance. NGOs concerned about such matters may also take note that MNEs may still be outmaneuvering them, and consider adopting new tactics in response. As to individuals, the conclusion may be that companies are only as honest as we force them to be. 


\section{REFERENCES}

Aguilera-Caracuel, J., Aragon-Correa, J. A., Hurtado-Torres, N. E. and Rugman, A. M. 2012. "The effects of institutional distance and headquarters' financial performance on the generation of environmental standards in multinational companies." Journal of Business Ethics 105(4): 461474.

Aguilera-Caracuel, J., Hurtado-Torres, N. E and Aragon-Correa, J. A. 2012. "Does international experience help firms to be green? A knowledge-based view of how international experience and organizational learning influence proactive environmental strategies," International Business Review 21(5): 847-861.

Aguinis, H. and Glavas, A. 2012. "What we know and don't know about corporate social responsibility: A review and research agenda," Journal of Management 38: 932-968.

Ahuja, G., and Katila, R. 2001. "Technological acquisitions and the innovation performance of acquiring firms: A longitudinal study," Strategy Management Journal 22: 197-220.

Alarcon, S., and Sanchez, M. 2013. "External and Internal R\&D, Capital Investment and Business Performance in the Spanish Agri-Food Industry," Journal of Agricultural Economics 64(3): 654675.

Arora, P. and Dharwadkar, R. 2011. "Corporate governance and corporate social responsibility (CSR): The moderating roles of attainment discrepancy and organization slack," Corporate Governance: An International Review 19: 136-152.

Bailey, W. and Spicer, A. 2007. "When does national identity matter? Convergence and divergence in international business ethics," Academy of Management Journal 50(6): 1462-1480.

Bansal, P. 2005. "Evolving sustainability: A longitudinal study of corporate sustainable development," Strategic Management Journal 26(3): 197-218.

Basu, K., and Palazzo, G. 2008. "Corporate social responsibility: A process model of sensemaking," Academy of Management Review 33: 122-136.

Baughn, C. C., Bodie, N. L., and McIntosh, J. C. 2007. “Corporate social and environmental responsibility in Asian countries and other geographic regions," Corporate Social Responsibility and Environmental Management 14: 189-205.

Baum C. F., Schafer D., and Talavera O. 2007. "The Effects of Short-Term Liabilities on Profitability: The Case of Germany," Money Macro and Finance (MMF) Research Group Conference 2006 61: Money Macro and Finance Research Group.

Becchetti, L., Di Giacomo, S., and Pinnacchio, D. 2008. "Corporate social responsibility and corporate performance: Evidence from a panel of US listed companies," Applied Economics 40(5): 541556.

Blodgett, M. S., Hoitash, R. and Markelevich, A. 2104. "Sustaining the financial value of global CSR: Reconciling corporate and stakeholder interests in a less regulated environment," Business and Society Review 119(1): 95-124. 
Bondy, K., Matten, D. and Moon, J. 2004. "The adoption of voluntary codes of conduct in MNCs: A three-country comparative study," Business and Society Review 109(4): 449-477.

Bourgeois L. J. III. 1981. "On the measurement of organizational slack," Academy of Management Review 6: 29-40.

Bowen, F. 2002. "Does size matter? Organizational slack and visibility as alternative explanations for environmental responsiveness," Business and Society 41: 118-124.

Campbell, J. L. 2007. "Why would corporations behave in socially responsible ways? An institutional theory of corporate social responsibility," Academy of Management Review 32: 946-967.

Chapple, W. and Moon, J. 2005. "Corporate social responsibility (CSR) in Asia: A seven-country study of CSR web site reporting," Business and Society 44: 415-441.

Chatterjee, S. 1990. "Excess resources, utilization costs, and mode of entry," Academy of Management Journal 33: 780-200.

Christmann, P. and Taylor, G. 2001. "Globalization and the environment: Determinants of firm selfregulation in China," Journal of International Business Studies 32(3): 439-458.

Chiu, S-C. and Sharfman, M. 2011. "Legitimacy, visibility, and the antecedents of corporate social performance: An investigation of the instrumental perspective," Journal of Management 37(6): 1558-1585.

Clarkson, P. M., Li, Y., Richardson, G. D. and Vasvari, F. P. 2011. "Does it really pay to be green? Determinants and consequences of proactive environmental strategies," Journal of Accounting and Public Policy 30(2): 122-144.

Christmann, P. and Taylor, G. 2006. "Firm self-regulation through international certifiable standards: determinants of symbolic versus substantive implementation," Journal of International Business Studies 37(6): 863-878.

Cohen, W. M., and Levinthal, D. A. 1990. “Absorptive capacity: A new perspective on learning and innovation," Administrative Science Quarterly 35: 128-152.

Dam, L.., Scholtens, B. and Sterken, E. 2007. "Corporate governance and international location decisions of multinational enterprises," Corporate Governance: An International Review 15: $1330-1347$.

de Jonge, A. 2011. "Transnational corporations and international law: Bringing TNCs out of the accountability vacuum," Critical Perspective on International Business 7(1): 66-89.

de Vita, G. and Kyaw, K. S. 2009. "Growth effects of FDI and portfolio investment flows to developing countries: A disaggregated analysis by income levels," Applied Economics Letters 16(3): 277283.

Delmas, M. A., Hoffmann, V. H. and Kuss, M. 2011. "Under the tip of the iceberg: Absorptive capacity, environmental strategy, and competitive advantage," Business and Society 50: 116-154. 
Eweje, G. 2009. "Labour relations and ethical dilemmas of extractive MNEs in Nigeria, South Africa and Zambia: 1950-2000," Journal of Business Ethics 86: 207-223.

Friedman, M. 1970. "The social responsibility of business is to increase profits," New York Times Magazine, September 13.

Ghemawat, P. 2007. Redefining Global Strategy. Boston, MA: Harvard Business School Press.

Gifford, B., Kestler, A., and Anand, S. 2010. "Building local legitimacy into corporate social responsibility: Gold mining firms in developing nations," Journal of World Business 45: 304311.

Halter, M. V., and de Arruda, M. C. C. 2009. "Inverting the pyramid of values? Trends in lessdeveloped countries," Journal of Business Ethics 90: 267-275.

Hart, S. L. 1995. "A natural-resource-based theory of the firm," Academy of Management Review 20(4): 986-1014.

Hitt, M. A., Ahlstrom, D., Dacin, M. T., Levitas, E. and Svobodina, L. 2004. "The institutional effects on strategic partner selection in transition economies: China vs. Russia," Organizational Science 15(2): 173-185.

Holtbrugge, D. and Dogl, C. 2012. "How international is corporate environmental responsibility?" Journal of International Management 18(2): 180-195.

Hull, C. E. and Covin, J. G. 2010. "Learning capability, technological parity, and innovation mode use," Journal of Product Innovation Management 27(1): 95-112.

Hull, C. E. and Rothenberg, S. 2008. "Firm performance: The interactions of corporate social performance with innovation and industry differentiation," Strategic Management Journal 29: 781-789.

Husted, B. W. and Allen, D. B. 2006. "Corporate social responsibility in the multinational enterprise: strategic and institutional approaches," Journal of International Business Studies 37: 838-849.

Ingram, P. and Silverman, B. 2002. "Introduction: The new institutionalism in strategic management," In Ingram, P. and Silverman, B. (Eds.), Advances in Strategic Management, 19: 1-30. Greenwich, CT: JAI Press.

Jamali, D. and Mirshak, R. 2007. "Corporate social responsibility (CSR): Theory and practice in a developing country context," Journal of Business Ethics 72: 243-262.

Jamali, D. and Mirshak, R. 2010. "Business-conflict linkages: Revisiting MNCs, CSR, and conflict," Journal of Business Ethics 93: 443-464.

Kennelly, J. J. and Lewis, E. E. 2002. "Degree of internationalization and corporate environmental performance: Is there a link?," International Journal of Management 19: 478-489.

Kim, Y. and Statman, M. 2012. "Do Corporations invest enough in environmental responsibility?" Journal of Business Ethics 105: 115-129. 
Kliukinskaitè-Vigil, V. 2011. "The effect of home and host country cultures on the manager's individual decision making related to ethical issues in a MNC," International Journal of Business Governance and Ethics 6(1): 1-27.

Kolk, A. and van Tulder, R. 2010. "International business, corporate social responsibility and sustainable development," International Business Review 19: 119-125.

Kostova, T., Roth, K. and Dacin, M. T. 2008. "Institutional theory in the study of multinational corporations: A critique and new directions," Academy of Management Review 33: 994-1006.

Lauder, T. 2010. "An attempt to determine the CSR potential of the International Clothing Business," Journal of Business Ethics 96: 63-77.

Levitt, T. 1983. “The globalization of markets," Harvard Business Review 61, 92-102.

Li, S., Fetscherin, M., Alon, I., Lattemann, C., and Yeh, K. 2010. "Corporate social responsibility in emerging markets: The importance of the governance environment," Management International Review 50: 635-654.

Lo, C. W. H., Egri, C. P. and Ralston, D. A. 2008. "Commitment to corporate, social, and environmental responsibilities: an insight into contrasting perspectives in China and the US," Organization Management Journal 5: 83-98.

$\mathrm{Lu}, \mathrm{J} ., \mathrm{Xu}, \mathrm{B}$. and Liu, X. 2009. "The effects of corporate governance and institutional environments on export behaviour in emerging markets," Management International Review 49: 455-478.

Luxmore, S.R. and Hull, C.E. 2011. "Innovation and NGOs: A framework of interaction," International Journal of Entrepreneurship and Innovation 12(1): 17-27.

Margolis, J.D. and Walsh, J.P. 2003. "Misery loves companies: Rethinking social initiatives by business," Administrative Science Quarterly 48: 268-305.

Madsen, P.M. 2009. "Does corporate investment drive a "race to the bottom" in environmental protection? A reexamination of the effect of environmental regulation on investment," Academy of Management Journal 52: 1297-1318.

McDonald, G.M. and Kan, P.C. 1997. "Ethical perceptions of expatriate and local managers in Hong Kong," Journal of Business Ethics 16: 1605-1623.

McWilliams, A. and Siegel, D. S. 2001. "Corporate social responsibility: A theory of the firm perspective," Academy of Management Review 26: 117-127.

McWilliams, A., Siegel, D. S., Wright, P. M. 2006. "Corporate social responsibility: Strategic implications,” Journal of Management Studies 43: 1-18. 
McWilliams, A. and Siegel, D. S. 2011. "Creating and capturing value: Strategic corporate social responsibility, resource-based theory, and sustainable competitive advantage," Journal of Management 37: 1480-1495.

Meyer, K. E., Estrin, S., Bhaumik, S. K. and Peng, M. W. 2009. Institutions, resources, and entry strategies in emerging economies," Strategic Management Journal 30: 61-80.

Miles, M. P., Munilla, L. S. and Covin, J. G. 2002. "The constant gardener revisited: The effect of social blackmail on the marketing concept, innovation, and entrepreneurship," Journal of Business Ethics 41: 287-295.

Miles M. P., Munilla, L. S. and Covin, J. G. 2004. "Innovation, ethics, and entrepreneurship,” Journal of Business Ethics 54: 97-101.

Moss, L. 2005. "Encouraging small cultural enterprises in Russia: Gateways and barriers in Russian society," International Journal of Entrepreneurship and Innovation 6(3): 193-200.

Mross, D. and Rothenberg, S. 2007. "Formulating and implementing environmental strategies: A comparison of U.S. and German printing firms," Environmental Quality Management Summer: 56-68.

Muller, J. 2012. "Death by hubris? The catastrophic decision that could bankrupt a great American manufacturer," Forbes. Accessed online (August 2, 2012):

http://www.forbes.com/sites/joannmuller/2012/08/02/death-by-hubris-the-catastrophic-decisionthat-could-bankrupt-a-great-american-manufacturer/

Murphy, D. D. 2005. “Interjurisdictional competition and regulatory advantage," Journal of International Economic Law, 8: 891-920.

Muthuri, J. N. and Gilbert, V. 2011. "An institutional analysis of corporate social responsibility in Kenya," Journal of Business Ethics 98: 467-483.

Orlitzky, M., Schmidt, F. L., and Rynes, S. L. 2003. "Corporate social and financial performance: A Meta-Analysis," Organization Studies 24: 403-441.

Peng, M. W. 2003. "Institutional transitions and strategic choices," Academy of Management Review 28: 275-296.

Peng, M. W. and Delios, A. 2006. "What determines scope of the firm over time and around the world? An Asia Pacific perspective," Asia Pacific Journal of Management 23, 385-405.

Peng, M. W., Wang, D. Y. L. and Jiang, Y. 2008. “An institution-based view of international business strategy: A focus on emerging economies," Journal of International Business Studies 39: 920936.

Peng, M. W., Sun, L. S, Pinkham, B. and Chen, H. 2009. "The institution-based view as a third leg for a strategy tripod," Academy of Management Perspective, August: 63-81.

Perrini, F., Russo, A. and Tencati, A. 2007. "CSR strategies in SMEs and large firms: Evidence from Italy," Journal of Business Ethics 74: 285-300. 
Pils, F. K. and Rothenberg, S. 2003. "Environmental performance as a driver of superior quality," Production and Operations Management 12: 404-415.

Porter M. E. 1980. Competitive Strategy, New York, NY: Free Press.

Porter M. E. 1996. “What is strategy?” Harvard Business Review 74(6): 61-79.

Porter, M. E. and Kramer, M. R. 2006. "Strategy and society: The link between competitive advantage and corporate social responsibility," Harvard Business Review 84(12): 78-92.

Porter, M. E. and Kramer, M. R. 2011. "Creating shared value: How to reinvent capitalism - and unleash a wave of innovation and growth," Harvard Business Review 89(1/2): 62-77.

Price, M. 2008. “Is environmental reporting changing corporate behavior?," International Journal of Business Governance and Ethics 4(2): 189-205.

Qerimi, Q. and Sergei, B. S. 2012. "The effects of economic freedom on institutional performance in the Western Balkans countries," International Journal of Business Governance and Ethics 7(1): 1836.

Reimann, F., Ehrgott, M., Kaufmann, L. and Carter, C. R. 2012. "Local stakeholders and local legitimacy: MNEs' social strategies in emerging economies," Journal of International Management 18(1): 1-17.

Reuer, J., and Ragozzino, R. 2005. “Agency hazards and alliance portfolios,” Strategic Management Journal 27: 27-43.

Ringov, D. and Zollo, M. 2007. "Corporate responsibility from a socio-institutional perspective: The impact of national culture on corporate social performance," Corporate Governance 7: 476-485.

Rothenberg, S. 2007. "Environmental managers as institutional entrepreneurs: The influence of institutional and technical pressures on waste management," Journal of Business Research 60: 749-757.

Russo, M.V. and Fouts, P. A. 1997. "A resource-based perspective on corporate environmental performance and profitability," Academy of Management Journal 40(3): 534-559.

Sandhu, S. 2010. "Shifting paradigms in corporate environmentalism: From poachers to gamekeepers," Business and Society Review 115(3): 285-310.

Shah, K. U., and Rivera, J. E. 2007. "Export processing zones and corporate environmental performance in emerging economies: The case of the oil, gas, and chemical sectors of Trinidad and Tobago," Policy Sciences 40: 265-285.

Shafer, W. E., Fukukawa, K., and Lee, G. M. 2007. "Values and the perceived importance of ethics and social responsibility: The US versus China," Journal of Business Ethics 70: 265-284.

Sharma, S. 2000. "Managerial interpretations and organizational context as predictors of corporate choice of environmental strategy," Academy of Management Journal 42: 681-697. 
Singh, J.V. 1986. "Performance, slack, and risk taking in organizational decision making," Academy of Management Journal 29: 562-285.

Slangen, A. H. L., and van Tulder, R. J. M. 2009. "Cultural distance, political risk, or governance quality? Towards a more accurate conceptualization and measurement of external uncertainty in foreign entry mode research," International Business Review 18: 276-291.

Souitaris, V., Zerbinati, S., and Liu, G. 2012. "Which iron cage? Endo- and exoisomorphism in corporate venture capital programs," Academy of Management Journal 55: 477-505.

Surroca, J., Tribo, J. A., and Waddock, S. 2010. "Corporate responsibility and financial performance: The role of intangible resources," Strategic Management Journal 31: 463-490.

Tan, J. 2009. "Institutional structure and firm social performance in transitional economies: Evidence of multinational corporations in China," Journal of Business Ethics 86: 171-189.

Tan, J. and Wang, L. 2011. "MNC strategic response to ethical pressure: An institutional logic perspective," Journal of Business Ethics 98: 373-390.

Tang, Z. and Hull, C. E. 2012. "An investigation of entrepreneurial orientation, perceived environmental hostility, and strategy application among Chinese SMEs," Journal of Small Business Management 50: 132-158.

Tang, Z., Hull, C. E., and Rothenberg, S. L. (2012) "How corporate social responsibility engagement strategy moderates the CSR-financial performance relationship," Journal of Management Studies 49: 1274-1303.

Tang, Z. and Smith, D. 2012. "How does state ownership affect pollution control? Evidence from the Chinese iron and steel industry," International Journal of Business Governance and Ethics 7(3): 173-190.

van Beurden P. and Gössling, T. 2008. "The worth of values - a literature review on the relation between corporate social and financial performance," Journal of Business Ethics 82: 407-424.

Waddock, S.A. and Graves, S.B. 1997. "The corporate social performance-financial performance link," Strategic Management Journal 18: 303-19.

Williamson, D., Lynch-Wood, G. and Ramsay, J. 2006. "Drivers of environmental behavior in manufacturing SMEs and the implications for CSR," Journal of Business Ethics 67: 317-330.

Yang, X. and Rivers, C. 2009. "Antecedents of CSR practices in MNCs' subsidiaries: A stakeholder and institutional perspective," Journal of Business Ethics 86: 155-169.

Zhou, J. Q and Peng, M. W. 2010. "Relational exchanges versus arm's-length transactions during institutional transitions," Asia Pacific Journal of Management 27: 355-370. 
Table 1

Means, Standard Deviations, and Correlations

\begin{tabular}{|c|c|c|c|c|c|c|c|c|c|}
\hline & 1 & 2 & 3 & 4 & 5 & 6 & 7 & 8 & 9 \\
\hline Mean & -.12 & .38 & .56 & .91 & -.09 & .79 & .07 & .05 & .02 \\
\hline $\begin{array}{l}\text { Standard } \\
\text { Deviation }\end{array}$ & .82 & .61 & .52 & .29 & .80 & .22 & .12 & .06 & .04 \\
\hline $\begin{array}{l}\text { 1. } 2009 \\
\text { Environmental } \\
\text { Performance }\end{array}$ & & & & & & & & & \\
\hline 2. Slack & -.01 & & & & & & & & \\
\hline 3.Size & -.03 & $.45^{* * *}$ & & & & & & & \\
\hline 4. Industry & -.04 & .01 & $-.35^{* * *}$ & & & & & & \\
\hline $\begin{array}{l}\text { 5. Past } \\
\text { Environmental } \\
\text { Performance }\end{array}$ & $.99^{* * *}$ & -.02 & -.03 & -.04 & & & & & \\
\hline $\begin{array}{l}\text { 6. High } \\
\text { Income } \\
\text { Market }\end{array}$ & .09 & $-.23^{* *}$ & -.12 & .07 & .04 & & & & \\
\hline $\begin{array}{l}\text { 7. Upper- } \\
\text { middle } \\
\text { Income } \\
\text { Market }\end{array}$ & -.11 & .08 & -.01 & .10 & -.08 & $-.60^{* * *}$ & & & \\
\hline $\begin{array}{l}\text { 8.Lower- } \\
\text { middle } \\
\text { Income } \\
\text { Market }\end{array}$ & $.19^{*}$ & -.10 & .10 & -.08 & $.20^{*}$ & $-.48^{* * *}$ & $.23^{* *}$ & & \\
\hline $\begin{array}{l}\text { 9. Low } \\
\text { Income } \\
\text { Market }\end{array}$ & -.02 & .05 & -.02 & .15 & -.02 & $-.49^{* * *}$ & $.43^{* * *}$ & $.35^{* * *}$ & \\
\hline
\end{tabular}


Table 2

Regression Results

\begin{tabular}{|c|c|c|c|c|}
\hline \multirow{3}{*}{$\begin{array}{l}\text { Dependent } \\
\text { Variable = }\end{array}$} & \multicolumn{4}{|c|}{2009 Environmental Performance } \\
\hline & \multicolumn{2}{|c|}{ Model 1} & \multicolumn{2}{|c|}{ Model 2} \\
\hline & Beta & Standard Error & Beta & Standard Error \\
\hline Slack & .02 & .03 & .05 & .03 \\
\hline Size & -.02 & .03 & -.03 & .03 \\
\hline Industry & -.02 & .05 & -.03 & .05 \\
\hline $\begin{array}{l}\text { Past } \\
\text { Environmental } \\
\text { Performance }\end{array}$ & $.99^{* * *}$ & .02 & $.97^{* * *}$ & .02 \\
\hline $\begin{array}{l}\text { High Income } \\
\text { Market }\end{array}$ & & & $.09^{* * *}$ & .09 \\
\hline $\begin{array}{l}\text { Upper-middle } \\
\text { Income Market }\end{array}$ & & & -.01 & .13 \\
\hline $\begin{array}{l}\text { Lower-middle } \\
\text { Income Market }\end{array}$ & & & $.04^{*}$ & .28 \\
\hline $\begin{array}{l}\text { Low Income } \\
\text { Market }\end{array}$ & & & $.04^{*}$ & .41 \\
\hline$R^{2}$ & & & & \\
\hline Adj. $R^{2}$ & & & & \\
\hline$F$ & & $4^{* * *}$ & & $1^{* * *}$ \\
\hline d.f. & & & & \\
\hline$\Delta R^{2}$ & & & & \\
\hline$\Delta F$ & & & & \\
\hline$\Delta d . f$. & & & & \\
\hline
\end{tabular}

